\title{
w The status of artisanal and small-scale mining sector in South Africa: tracking progress
}

\author{
by P.F. Ledwaba*
}

\section{Synopsis}

Artisanal and small-scale mining (ASM) in South Africa received official recognition after the change in government in 1994.The Reconstruction and Development Programme (RDP) recognized the sector as a vehicle for social and economic development for historically disadvantaged South Africans (HDSAs) who had previously been excluded from participating in the mainstream economy. Having recognized the ASM sector, government introduced several interventions and support structures to foster the development of ASM, to encourage participation of HDSAs, and to address challenges facing the sector. The objective of this paper is to assess the progress made, with particular regard to challenges in the sector. The paper focuses on the policy requirements that were deemed important for the growth of the ASM sector by the White Paper on Minerals and Mining Policy (1998). These can be collated into five categories: access to mineral rights, access to finance, access to markets, technology and skills, and institutional support. The paper provides a review of the support interventions, their intended roles and impact on the sector, and identifies existing gaps and possible ways of dealing with the challenges. There is a need for research to assess the real impact of these past and existing interventions on the ASM sector to draw lessons for future development.

\section{Keywords}

artisanal and small-scale mining, disadvantaged communities, policy requirements, intervention strategies, socio-economic benefits.

\section{Introduction}

The significant rise in artisanal and smallscale mining (ASM) activities worldwide has led to many countries recognizing the sector. ASM takes place in approximately 80 countries (World Bank, 2013). It is estimated that the sector employs between 20 and 30 million people around the world (Buxton, 2013). This compares to between 3 and 3.7 million in 1999 (International Labour Organization, 1999). ASM activities are widespread, occurring mostly in developing countries in Africa, Asia, Oceania, and Central and South America (World Bank, 2013). There has been a significant increase in the number of people participating both directly and indirectly in the sector and this is expected to continue given the socio-economic realities of most developing countries. High levels of poverty and unemployment and growing inequality continue to be largest problems facing the majority of developing countries today. The ASM sector plays an important role as a source of livelihoods, particularly for those residing in rural areas with limited economic opportunities. In the majority of countries, the recognition of the ASM sector was driven by its increasing contribution to socio-economic development through job creation, poverty alleviation, and rural development. In response, a number of intervention strategies were introduced in support of the sector to address its negative impacts and to increase its potential benefits.

The ASM sector in South Africa was first recognized in 1994 as a vehicle to foster social and economic growth through participation of historically disadvantaged South Africans (HDSAs) in the mining industry. However, since recognition, there have been limited growth opportunities for both aspiring and existing small-scale miners. Small-scale miners are still faced with a number of challenges relating to access to mineral rights, access to capital, access to markets, inadequate skills and knowledge, access to information, access to appropriate technology, and lack of institutional support (Nellie and Petersen, 2002; Hoadley and Limpitlaw, 2004; Department of Mineral Resources, 2011; Ledwaba and Nhlengetwa, 2016). As is the case in many other African countries, South Africa continues to struggle to transform the ASM sector despite the implementation of several support programmes. While interest has grown from disadvantaged communities wishing to enter and participate in the mining

* Centre for Sustainability in Mining and Industry (CSMI), University of the Witwatersrand, South Africa.

(1) The Southern African Institute of Mining and Metallurgy, 2017. ISSN 2225-6253. This paper was first presented at the Mining, Environment and Society Conference 'Beyond sustainabilityBuilding resilience', 12-13 May 2015, Mintek, Randburg, South Africa. 


\section{The status of artisanal and small-scale mining sector in South Africa}

industry, the formal ASM sector remains small compared to other countries with relatively similar mineral endowments (e.g. Zimbabwe and Mozambique) ${ }^{1}$. The majority of ASM activities in South Africa take place outside the formal structures created to regulate and manage the sector.

This paper reviews the past and present interventions introduced to facilitate the development of the ASM sector in South Africa. The paper focuses on the five key challenges identified as being crucial to the success of the sector by the White Paper on Minerals and Mining Policy released in 1998. These are: access to mineral rights, access to finance, access to markets, technology and skills, and institutional support.

\section{The development of the ASM sector in South Africa}

South Africa has a long history of mining, both on a small scale and large scale. The discoveries of copper followed by diamonds and gold were the first mining activities to be recorded in the country. The history of the mining industry focused largely on the emergence of the large-scale mining (LSM) industries in the country. This is despite evidence that ASM activities took place long before the emergence of large modern mining industries. There are studies which suggest that large mining industries started as artisanal and smallscale mining operations (e.g. the case of copper mining in Namaqualand in the Northern Cape Province) ${ }^{2}$. ASM is not a new activity in South Africa, but it was largely ignored by the apartheid regime (Solomon, 2012) and became part of the national agenda only after the change in government after 1994.

ASM was among the key socio-economic programmes identified in the Reconstruction and Development Programme (RDP) - a policy framework aimed at eradicating past injustices created by the apartheid government (Government Gazette, 1994). The ASM sector was earmarked to redress imbalances of ownership created by the apartheid regime in the mining industry through the empowerment of disadvantaged communities, the provision of skills, the stimulation of entrepreneurial spirit in South Africa, and better utilization of mineral resources (African National Congress, 1990). As part of its recommendations to the resource-based industries, the RDP urged government to 'consider ways and means to encourage small-scale mining and to enhance opportunities for participation by our people through support, including financial and technical aid and access to mineral rights' (Government Gazette, 1994).

In 1998, the Minerals and Energy Policy Centre (MEPC) undertook a study on small-scale mining in South Africa. The objective of the study was to provide an overview of smallscale mining activities in South Africa with specific focus on the contribution of the sector to the economy, and existing practices in terms of compliance, interaction with institutions, and institutional support. The study was also aimed at providing recommendations on the extent to which the sector should be promoted (Scott et al., 1998). In its conclusion, the

\footnotetext{
${ }^{1}$ The number of people participating in the ASM sectors in Mozambique and Zimbabwe is estimated at 60000 and 500000 respectively (Buxton 2013)

2http://www.mintek.co.za/Pyromet/Files/2015Jones-Copper.pdf [Accessed 8 August 2016]
}

study stated that: 'Small-scale mining development in South Africa should focus on the fostering of an efficient and effective small and junior sector that can drive exploration and cost-effective mining development in the country [...] to achieve this, issues such as legislation of illegal operators, finance, mineral and land rights access, and training all needs to be addressed' (Scott et al., 1998).

The ASM agenda was further supported by the White Paper on Minerals and Mining Policy of South Africa which was released in October 1998. With a dedicated section on small-scale mining, government's objective was to 'encourage and facilitate the sustainable development of small-scale mining in order to ensure the optimal exploitation of small mineral deposits and to enable this sector to make a positive contribution to the national, provincial and local economy' (Department of Minerals and Energy, 1998). The Minerals and Mining Policy was centred on three pillars, and these related to: the development of the ASM sector; encouraging participation of disadvantaged communities; and addressing challenges in the sector. The ASM sector in South Africa was faced with a wide range of challenges, including access to mineral rights, limited financial opportunities, access to mineral deposits, lack of technical skills, poor access to markets, and regulatory and administrative requirements (Department of Minerals and Energy, 1998).

Over the past two decades, the government established several programmes to facilitate the development of the ASM sector. Section 1.4.4.2 (clause vii) of the White Paper on Minerals and Mining Policy of South Africa stated that 'the DME will facilitate small-scale mining support on the broad spectrum of activities [...] and will further facilitate the establishment of a self-sustaining institutional support mechanism for small-scale mining'. It was based on these policy requirements that a number of programmes to support and develop the ASM sector were established.

\section{Current status of the ASM sector}

ASM in the country is relatively young compared to other countries (using 1994 as a benchmark). As in many countries, the biggest motivations to participate in ASM activities are high unemployment rates and high levels of poverty. ASM activities in South Africa take place mostly in rural areas with known mineral availability. The number of people participating in the sector is estimated between 10000 and 30000 (Mutemeri and Petersen, 2002; Buxton, 2013). To date, no proper baseline study has been conducted and hence these figures might not be a reflection of the situation on the ground.

There have been reports suggesting that the sector has grown considerably (Ledwaba and Nhlengetwa, 2016). Ledwaba and Nhlengetwa attributed this to the Mineral and Petroleum Resources Development Act (MPRDA) which was enacted in 2002. The release of the MPRDA saw an increased interest from the public to participate in and enter the mining industry. According to the DMR, there has been an increase in the number of mining permits issued. A total of 103 and 141 mining permits were issued in 2005 and 2006 respectively (DMR, 2011). Figure 1 shows the number of permits issued in each province between 2004 and 2010. Although this is not a conclusive representation the size of the sector, it provides an idea of the level of interest and distribution of 


\section{The status of artisanal and small-scale mining sector in South Africa}

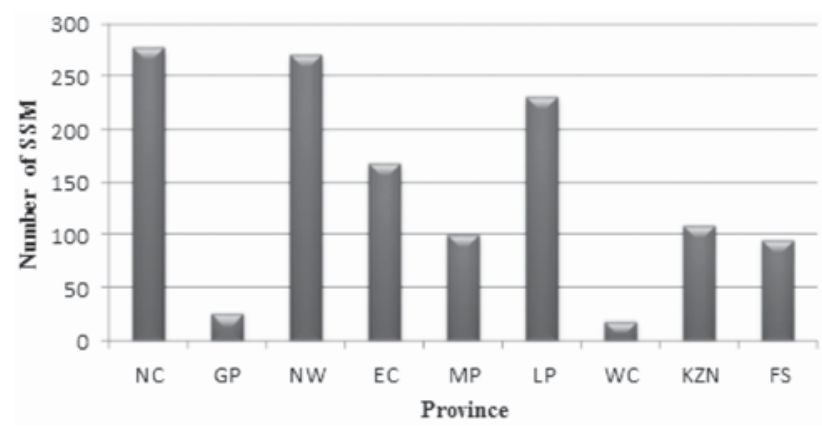

Figure 1-Number of mining permits issues between 2004 and 2010 per province (from database provided by the DMR)

ASM activities in the country. Over 1000 permits were issued between 2004 and 2010. It must be noted that the distribution of ASM activities depends on several factors such as mineral availability, capital availability etc.

A study conducted by the Mine Health and Safety Council (MHSC) in 2011 estimated the number of registered smallscale mines to be 1030. The first case studies of ASM operations documented were of rural women in KwaZuluNatal mining kaolin, diamond miners in the Northern Cape, women miners extracting coal for brickmaking in KwaZuluNatal, and gold miners in the Barberton area in Mpumalanga (Dreschler, 2001). ASM activities have since grown and expanded to all nine provinces across South Africa. However, they are more widespread in poverty-stricken regions such as the Northern Cape, North West, Limpopo, and Eastern Cape provinces. These are provinces with high levels of unemployment (the unemployment rate is above the national average) (Statistics SA, 2016).

Today, the bulk of ASM operations exploit industrial minerals and construction materials. According to the DMR, over 90 per cent of small-scale mining operations exploit these minerals (Mutemeri et al., 2010; Mining Qualifications Authority, 2014). Industrial minerals (IM) have been deemed suitable for small-scale mining in the country (Department of Mineral Resources, 2011; Dlambulo and Motsie, 2014). While South Africa holds significant deposits of industrial minerals, the IM sector has received inadequate attention until recently. A significant percentage of IM remain underexploited in South Africa largely because of their low economic value compared to the gold and platinum group minerals (Malatsi $e t$ al., 2014). Furthermore, the IM sector presents an opportunity for South Africa to diversify the mineral portfolio, especially during times when the high-value mineral commodities such as gold and platinum group elements perform poorly. IM are also deemed suitable for small-scale mining because they are: found near the surface, are easy to mine and beneficiate, and they allow the use of simple equipment and machinery (Dlambulo and Motsie, 2014). As key inputs in the construction industry, the demand for IM is expected to increase, creating opportunities for emerging and existing small-scale miners across South Africa.

Although opportunities for small-scale miners exist, the majority of them are unable to leverage the opportunities because they operate outside the legal framework. Illegal mining remains a critical issue in the ASM sector globally. It is known that the majority of ASM activities are conducted outside the legal framework. According to the South African Human Rights Commission (2015), up to 30000 people have been involved in illegal mining in the past 10 years. In 1999, the Department Minerals and Energy reported the number of illegal miners in South Africa to be around 3000 (Engineering News, 1999). This implies that in just over 15 years, the number of illegal miners in South Africa has increased tenfold. Illegal mining activities continue to escalate despite government's intervention through the creation of a mining permit to allow small-scale miners to operate within the required regulatory framework. In the majority of areas, aspiring and existing miners are aware of the legal requirements and the processes for obtaining legal permission. However, the costs to obtain the permission remain a challenge for most of them.

Entry to the sector has become difficult, with only a few being able to afford the financial obligations. As a result, the profile of small-scale miners is changing. The formal ASM sector is made up emerging entrepreneurs with the necessary financial resources rather than disadvantaged and poor communities. As things stand, the current regulatory framework favours those with the financial means and not those from poor backgrounds. This reality then brings into question the objectives and intended role of the MPRDA, particularly on small-scale mining development.

It is important to note that illegal mining activities in South Africa are not limited to the gold sector - they take place in other mineral sectors as well. The gold sector appears to receive more media coverage because of its association with criminal activities and dangerous working conditions, which have resulted in a number of fatalities. A recent report by the Chamber of Mines (2016) estimated the number of people involved in illegal mining to be 14000 , while the value of the industry was estimated at R6 billion annually. According to the Chamber of Mines (2016), 'illegal artisanal mining is on the rise in South Africa and presents challenges that need to be addressed from a range of perspectives'. The main causes of illegal mining activities, particularly in the gold sector, are mine closure, mineworker retrenchments, high unemployment rates, high levels of poverty, declining gold price, immigration, and narrowing of formal channels of entry (Nhlengetwa, 2016).

There is currently no reliable data on the extent of illegal mining activities in South Africa. However, from available literature and reports, it can be deduced that the ASM sector in South Africa consists of three broad activities: registered operations that are legal, the 'traditional' activities operating outside the legal framework (also referred to as informal mining operations), and the Zama-Zama type mining.

The latter group consists of artisanal and small-scale miners who also operate outside the legal framework but their activities are associated with criminality and organized crime. These miners operate mostly in abandoned shafts (Nhlengetwa and Hein, 2015).

\section{The status update on policy requirements}

The key challenges facing the ASM sector can be grouped into five main themes: access to mineral rights, access to capital, access to markets, technology and skills, and institu- 


\section{The status of artisanal and small-scale mining sector in South Africa}

tional support. These challenges were raised by the miners on the ground during the consultation processes as part of the drafting of the White Paper on Minerals and Mining Policy. These have been the main focus of support interventions during the past 20 years.

It is important to acknowledge that the development of the sector depends on a number of stakeholders involved in the sector directly or indirectly. Amongst the key challenges identified in the sector was the lack of appropriate structures to assist with small-scale mining development in the country. During the consultation processes, the miners expressed the need for an integrated and coordinated approach encompassing government departments and other relevant supporting agencies to promote and develop the sector (Minerals and Mining Policy, 1998). These included government and other related institutions with the necessary experience and expertise to assist with the development of the sector. There have been great efforts, particularly from government, to satisfy these objectives. In fact, the majority of support interventions have been spearheaded by government. Due to the multifaceted nature and the complexities resulting in dealing the challenges facing the ASM sector, government continues to work with other key role players to transform the sector. The subsequent sections provide an assessment of the progress made in addressing the five key challenges.

\section{Access to mineral rights}

In the past, South Africa used a dual system whereby some mineral rights belonged to the State and some to private holders (Minerals and Mining Policy, 1998). This made it difficult for the majority to own or access mineral rights. The main concerns relating to mineral rights access as it pertains to small-scale mining have been largely around qualifying for formal mineral rights and finding land or suitable deposits (Scott et al., 1998). According to the study conducted by the Minerals and Energy Policy Centre, all operators that participated in the research faced difficulties in accessing viable mineral deposits (a total of 79 operations). The reason provided for this was that good potential deposits were under the control of large mining companies as part of their longerterm production strategies (Scott et al., 1998). The following recommendations were proposed to address issues around access to minerals rights (Government Gazette, 1998):

$>$ Small-scale miners require information on the availability of mineral rights and mineral deposits

> Unfragmented and adequate information is required on mineral regulations, geology, mining and environmental aspects, and mineral marketing

- Regulations in respect of mining should be relevant, understandable, and affordable to the small-scale miner

$>$ Administrative procedures need to be simplified and speeded up.

The new democratic dispensation saw the enactment of new legislative frameworks across different sectors of the economy as a way to take back control and open economic sectors to the majority of South Africans. The MPRDA came into effect on 1 May 2004 to lead the transformation of the mining industry. Part of the agenda of the MPRDA was to discard the past discriminatory mineral laws such as the dual system of mineral rights. The MPRDA transferred ownership of privately held mineral rights to the State to allow participation of HDSAs. Under the MPRDA, all mineral resources belong to the people under the custodianship of the State. This implies that anyone can apply for a license to prospect and/or mine. The MPRDA recognizes all form of mining activities, including small-scale mining. While the Act does not clearly distinguish between the different categories of mining, it makes provisions for small-scale mines in the form of a mining permit. A mining permit is a document issued by the Department of Mineral Resources which allows one to conduct mining operations. Section 27 of the MPRDA states that a mining permit is issued only if:

$>$ The mineral in question can be mined optimally within a period of two years

> The mining area in question does not exceed 1.5 hectares in extent (this has since been increased to 5.0 hectares).

The mining permit was introduced solely to provide a platform for HDSAs that is affordable and easy to access. The DMR differentiates small-scale mining activities into three types, namely artisanal or subsistence mining operations (new entrants), sub-optimal formal mining operations, and entrepreneurs with upfront capital ${ }^{3}$. Although mining permits are less costly compared to mining rights (designed for LSM), small-scale miners are expected to meet the requirements with respect to the Environmental Management Plan, consultation with the landowner/ occupier and affected parties, financial provision for rehabilitation, and proof of technical ability. Due to the wide spectrum of ASM activities (and hence disparities in affordability), the requirements of the mining permit are not 'easy and affordable' to everyone. For the majority, financial requirements remain the largest entry barrier.

The other key issue raised by small-scale miners relates to the administrative processes, which are deemed complex. The DMR started off with a manual system for lodging and granting mining licences. However, in 2011, a move was made to an online system known as the South African Mineral Resources Administration Online System (SAMRAD). SAMRAD was launched in April 2011 with the primary objective of improving the application process (DMR, 2012). While the online system was welcomed by the industry, small-scale miners encountered challenges and as a result they have not fully accepted the system. The common concerns of small-scale miners are that:

> The system is too advanced and complicated

> They have no access to computers and the internet

- Internet cafes are expensive

- Application fees can only be paid electronically There are also concerns around the geographical locations of the DMR regional offices

> There are few satellite offices in rural areas

> Regional offices are located in major towns far from rural areas

> There is only one dedicated office in most provinces

3http://www.dmr.gov.za/small-scale-mining.html [Accessed 15 December 2016] 


\section{The status of artisanal and small-scale mining sector in South Africa}

> There is only one person dealing with small-scale miners' challenges in the province (Focus group discussion, 2014).

Small-scale miners have also raised concerns around conflicts with traditional leaders, particularly in rural areas where communities are still under the rule of traditional leaders or chiefs. Traditional leaders have been accused of controlling mineral deposits and refusing to grant permission to community members to mine (DMR, 2015). Although the MPRDA requires applicants to consult and obtain permission from interested and affected parties, it is suggested that traditional authorities usually make decisions with respect to access to mineral rights. While the DMR conducts community workshops to educate and raise awareness on mineral rights and the requirements thereof, the distinction between mineral rights laws and surface rights laws is still not well comprehended, particularly in rural and traditional communities. This has been the cause of conflicts in some areas.

Notwithstanding the existing challenges, the MPRDA has made inroads in addressing some of these challenges. For instance, the MPRDA has managed to create an enabling environment to foster participation of disadvantaged communities. Through community workshops and education programmes, there is increased awareness across the country. This has resulted in most communities being aware of mineral deposits in their areas and the mining and beneficiation opportunities around them. South Africa has also seen an increase in interest from communities to enter and participate in mining. The MPRDA has managed to open up the industry, particularly to women and the youth who perceive mining as potential business ventures. In spite of the challenges of obtaining mining licences, the majority across the country is aware of the regulatory and administrative processes and requirements thereof. The main barrier to mineral rights access is the hefty costs.

Other policy issues relate to the provisions of the mining permit. It has been argued that the restrictions in areal extent and mining duration limit the sustainable growth of the sector (DMR, 2014). Common practice has been to apply for several mining permits to increase the mining area. As part of the proposed amendments in 2008, the MPRDA increased the areal extent from 1.5 hectares to 5 hectares (MPRDA Amendment Act 2008). There is currently a proposal in the MPRDA Amendment Bill to increase the mining duration to a total of 7 years as opposed to 5 years (after renewals). This is still under review, but some small-scale miners feel that it is still too little considering the size of the deposit they are exploiting (for example salt miners).

\section{Access to funding}

Mining (whether large or small) is a risky business given the level of uncertainties. The bulk of small-scale mining operations are in a much worse position than large-scale operations. This is because the level of uncertainties extends far beyond those experienced by LSM operations. This is brought about by the lack of knowledge in terms of: mineral resource potential, lifespan of the deposit, economic value of the deposit, market availability, cash flows, and skills and capacity. Most financial institutions do not offer any financial assistance to small-scale miners.
Small-scale miners are usually funded through three channels: government initiatives, donor organizations, and/or middlemen (buyers) (Dreschler, 2001). The latter option is most common where miners enter into contracts with buyers to invest into the business (e.g. in the form of capital or equipment) in exchange of selling products solely to them or at pre-determined prices. In the majority of cases, this has not proven feasible and has resulted in exploitation because of inequalities in bargaining powers (e.g. tiger's eye mining in Northern Cape Province) (Ledwaba et al., 2013).

Government has also established initiatives to provide funding for both aspirant and existing miners. In 2000, the DMR established the National Steering Committee of Service Providers (NSC) as part of the National Small Scale Development Framework. The principal objective of the NSC was to provide technical, managerial, and financial support to small-scale mining projects (Dreschler, 2001; Mutemeri and Petersen, 2002; Department of Mineral Resources, 2011). The funding was structured such that 90 per cent was offered as a loan and the remaining 10 per cent was to be raised by the applicant. The funding was meant to be used to purchase equipment, provide rehabilitation guarantees, and cover operational costs. The poor outcomes of the programme led to its being discontinued in 2005. The majority of the projects failed to repay the loans. The NSC was replaced with the Small Scale Mining Board (SSMB) in 2006. According to Mutemeri et al. (2010), a total of 197 projects were handled, 173 of which were mining and 24 were beneficiation projects. It is not clear how many projects were supported technically and/or financially, but an article published in 2015 in Mining Weekly reported that R15.1 million was allocated to assist 20 small-scale mining projects (Solomons, 2015). While these programmes were able to assist some small-scale mining projects to become viable, overall results are not visible. The DMR has since stopped providing funding to small-scale miners.

No impact assessment has been done to evaluate the performance of these projects. While on site, it was discovered that some projects have been abandoned with equipment and machinery vandalized at some operations. The projects which are still active are still struggling and operate on a hand-to-mouth basis (the case of sandstone miners in the Free State). There are very few success stories. The failure of most projects is related to the following gaps: the lack of business skills, management skills, and lack of capacity from the DMR to monitor and support projects.

\section{Access to markets}

Access to markets is a major challenge for most small-scale miners. This is because most of these operations are located in remote areas and far from major markets. In addition, the majority of operations lack the requisite marketing skills and knowledge to identify and compete in major markets. Most operations rely of word-of-mouth advertising and referrals as the only means of marketing. Common markets for ASM constitute small markets and these comprise individual customers and small businesses operating in their areas.

Market opportunities for small-scale operations have been identified in the industrial minerals sector. Industrial minerals are defined as 'any rock, mineral or other naturally occurring substance of economic value, exclusive of metal 


\section{The status of artisanal and small-scale mining sector in South Africa}

ores, mineral fuels and gemstones' (Kogel et al., 2006). Regarded as high-volume and low-value minerals, industrial minerals remain underexploited in South Africa and hence present opportunities for small-scale miners. Some of these potential opportunities include salt production and sandstone mining. Salt resources in South Africa are estimated at $53 \mathrm{Mt}$ and currently only 50 per cent of the demand is met (DMR, 2007). This presents a potential opportunity for salt miners in South Africa. There are also opportunities in the sandstone industry. While South Africa holds significant sandstone deposits, end-users are importing sandstone from neighbouring countries, chiefly Lesotho. There are a number of domestic market opportunities for small-scale operators, particularly those producing industrial minerals and construction materials. The demand for industrial minerals is expected to rise on the back of increased demand for construction materials, which is driven by the massive Government Infrastructure Built Programme (Dlambulo and Motsie, 2014). The public sector has spent more than R2.2 trillion on infrastructure between 1998 and 2015 (National Treasury, 2015).

Some of the key interventions identified as important in terms of supporting of small-scale operations include improved technology, value addition, and access to finance. In addition, organization of small-scale miners and improved knowledge of markets have been identified as key interventions (Common Fund for Commodities, 2008).

\section{Technology and skills}

The level of technology deployed in the ASM sector is characterized as low. It ranges from rudimentary tools (no mechanization) to mechanization on a limited scale. The majority of operations depend on manual labour and the use of basic tools (such as pick and shovel) is very common. The need for appropriate technology in the sector is driven by the need to improve operations to ensure that they are organized, safe, and environmentally sound.

The lack of technology in the sector is partly a result of the lack of research on the sector, and of funding to support research. Several technologies have been developed in the sector, particularly for miners involved in gold mining. These technologies were developed to eliminate the use of mercury during the gold recovery process. Mercury is widely used by artisanal gold miners to extract gold and it constitutes a serious health and safety risk to humans and the surrounding environment. This can either be through direct inhalation or through the consumption of contaminated water, animals, or crops.

Extensive research has been undertaken to reduce, and ultimately eliminate, the use of mercury (Common Fund for Commodities, 2008). Examples of such technologies are ThermEx retort, borax, and iGoli mercury-free technology. The iGoli Technology is a product of Mintek, one of South Africa's science councils. The iGoli technology uses pool acid and bleach to extract gold with recoveries of 99 per cent. However, while it has been proven technically, it has been a struggle to induce small-scale operators to use the technology because of the cost involved, and the perceptions of miners towards the technology have also played a huge role. The reluctance to adopt technology can be attributed to inadequate training and support, no application of local knowledge (indigenous knowledge), cost of intellectual property, lack of consultations with the miners, inadequate needs analysis, and cost of equipment (Mutemeri, 2016; Hilson, 2015).

The need for training and skills was identified as a requirement for the ASM sector. While the shortage of skills in the mining industry is not unique to the ASM sector, small-scale miners often lack the primary skills to conduct mining operations. Mintek established the Artisanal and Small Scale Mining School in 2004 following the introduction of Skills Development Act (No. 97 of 1998), MPRDA, and South African Qualifications Authority Act (No. 58 of 1995). The training programmes offered are accredited by the MQA and are conducted in accordance with the requirements and standards set out by the MQA. The courses offered include introduction to small-scale mining, mineral beneficiation, health and safety, surface mining, and underground hardrock mining. Since its inception, the School has trained well over 2000 participants across the country.

Figure 2 provide the profiles of participants according to age group. The training programme targets largely communities in rural and marginalized areas. Over 90 per cent of the participants are black South Africans. Of those trained, more than 50 per cent of the participants were women. There is also a fair representation across different age groups. It is interesting to note that there is still considerable interest from older participants ( $>50$ years) to enter and participate directly in the mining industry.

The training programme has contributed positively to the development of the ASM sector, as well as making inroads in terms of educating communities and raising awareness to stimulate interest from HDSAs. The programme has also contributed to improvements in health and safety at existing operations. However, a monitoring and evaluation study of 47 participants in the programme revealed that none of them had been able to obtain mining permits due to lack of financial resources, costs associated with the license application, and title deeds issues (Legoale, 2014).

\section{Institutional support}

The lack of structures to support and carry forward the responsibility of assisting small-scale miners was identified as one of the critical gaps in ensuring the development of the sector. This was one of the recommendations made by the Mining, Minerals and Sustainable Development (MMSD) report, which called for partnerships between government bodies, educational institutions, private companies, and

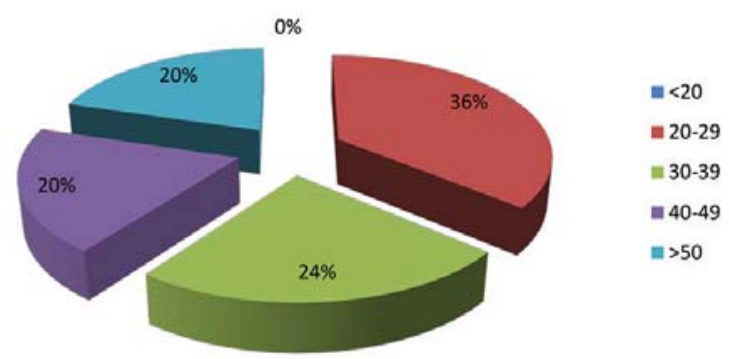

Figure 2-Participants in Mintek's ASM training programme according to age group (Legoale, 2014) 


\section{The status of artisanal and small-scale mining sector in South Africa}

donors. The idea behind partnerships was to establish a coherent structure that will address the needs of the ASM sector. This was based on the perception that challenges facing the sector are interrelated, and hence a holistic problem-solving approach is critical.

Access to information was also identified as a key required by the Minerals and Mining Policy. Small-scale operators often lack the necessary information, particularly regarding the location of minerals, geology and mineral quality, technical mining and processing techniques, minerals marketing, regulatory and legislation issues, and compliance. Part of the responsibilities of the dedicated structure/s was to provide the necessary information to both aspiring and existing miners.

The government, through the DMR (then the Department of Minerals and Energy), took the lead in establishing support structures for ASM development. As mentioned previously, government established several programmes to facilitate the development of the ASM sector. These include the National Small Scale Development Framework (1999), National Steering Committee of Service Providers (NSC) (2000), Small Scale Mining Directorate (2004), and Small Scale Mining Board (2006). The principal objective of these initiatives was to provide technical, managerial, and financial support to small-scale mining projects (Dreschler, 2001; Mutemeri and Petersen, 2002; Department of Mineral Resources, 2011). In parallel to these government-led programmes, associated institutions introduced assistance programmes to support the development of small-scale mining. The MQA, in partnerships with key role-players, developed qualifications, learnerships, and skills programmes for small-scale mining (Solomon et al., 2012). According to the MQA, a total of 350 learners in all nine provinces, including women, received small-scale mining technical training (Mining Qualifications Authority, 2014). However, the MQA has reported that the training has been discontinued because its impact to the sector is unclear (MQA, 2014).

There is limited information on the impact of these programmes on the small-scale mining sector. Participants in a study conducted by Marriot (2008) on small-scale mining in KwaZulu-Natal attributed the poor performance to lack of skills and capacity within the Department, lack of continuity, and poor stakeholder communication and co-ordination.

Institutional support has been a learning curve for government and related institutions. While most of the aforementioned programmes have been discontinued, most of the institutions still offer assistance to small-scale miners. The DMR has a dedicated Directorate that assists small-scale operators. The services provided include the establishment of a legal entity, guidance towards the identification of mineral deposits, the compilation of environmental impact assessments (EIAs), reserve estimation, and mining feasibility and market studies. There is still a need for an 'assistance body' to promote the sector - similarly to the structure of the NSC. There is a need to investigate the impact of these programmes on the development of the sector, to identify successes and failures, and draw lessons for future interventions. Figure 3 provides areas of intervention for small-scale miners along the mine value chain and recommends key stakeholders that could take the lead in these initiatives.

There are a number of stakeholders with the necessary experience and expertise to address the challenges experienced by small-scale operators. There is a need to establish synergies and collaborative efforts between different stakeholders. The African Mining Vision links the poor performance of past interventions to the top-down, adhoc approaches which mostly lack continuity and adequate funding (African Mining Vision, 2009). It is argued that the top-down initiatives fail to take cognisance of the inherent structural challenges of ASM (Buxton, 2013). In the majority of countries, the central government is responsible for all processes including policy formulation, administration, regulation, implementation, and even monitoring and evaluation. South Africa finds itself in a similar situation where the majority of institutions supporting ASM are national bodies, although there is some representation at the regional level - but not at grassroots level. There is therefore a need to increase the involvement of local organizations. According to Hoadley and Limpitlaw (2004), the low involvement of local and municipal government in ASM initiatives and programmes impacts on the success of these programmes. The need to involve local authorities is increasingly cited as important in ensuring that the right support is provided on the ground.

\section{Conclusion: the future of the ASM sector}

It is difficult to measure progress and the impact of support interventions on the development of the ASM sector. This is largely because of the lack of data on the sector and the interventions themselves. In the few available studies, there is no reliable data with respect to the exact number of people employed by the sector, range of activities, geographical

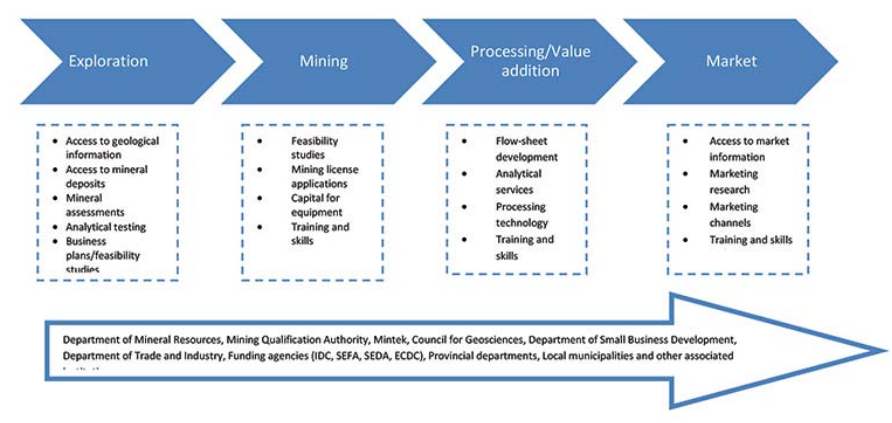

Figure 3-Key areas of intervention for small-scale miners 


\section{The status of artisanal and small-scale mining sector in South Africa}

distribution, demographic profiles, and its contribution to the economy. However, through field experience, it has been observed that ASM activities in South Africa are widespread, occurring in all nine provinces. The majority of small-scale miners exploit industrial minerals such as sand and aggregates, clay minerals, and dimension stone. The challenges facing the sector today are similar to those when the sector was formally recognized. The major challenges remain access to minerals rights, finance, and markets, appropriate technology and skills, and a structured support framework. The past efforts introduced to support the sector have made inroads in addressing some of these issues. There is therefore a need for research to assess the real impact of past and existing interventions on the ASM sector to draw lessons for future development. The ASM sector is an important sector in the economy. Experience in other countries suggests that if the sector is well supported, it could results in socio-economic benefits for local communities and the country as a whole.

\section{Acknowledgement}

This research was conducted at both the Centre for Sustainability in Mining and Industry (CSMI) at the University of the Witwatersrand and Mintek. The author would like to extend gratitude to both institutions.

\section{References}

African National Congress (ANC). 2004. Draft Mineral and Energy Policy. http://www.anc.org.za/show.php?id=253 [Accessed 11 April 2016].

Buxton, A. 2013. Responding to the challenge of artisanal and small-scale mining. How can knowledge networks help? International Institute for Environment and Development.

Chamber of Mines. 2016. Illegal and artisanal mining. Fact sheet 2016. Johannesburg, South Africa.

Common Fund For Commodities. 2008. Regional Workshop: Small-scale Mining in Africa - A Case for Sustainable Livelihood. November 2008.

Department of Mineral Resources. 2007. Structure of the salt industry in the Republic of South Africa. Mineral Economics. Report R62/2007. Pretoria.

DePARTMEnT of Mineral Resources. 2011. Nurturing Junior Miners of the Future: A Strategic Framework to facilitate the growth of small scale mining sector in South Africa. Pretoria.

Department of Mineral Resources. 2012. Annual Report 2011/2012. http://www.gov.za/sites/www.gov.za/files/Department_of_Mineral_Resour ces_annual_report_2011_2012.pdf [Accessed 8 August 2016].

Department of Mineral Resources. 2015. Community workshop. Mpakeni Tribal Authority, White River, Mpumalanga. 4 August 2015.

Department of Minerals and Energy (DME). 1998. A Minerals and Mining Policy for South Africa. Department of Minerals Resources. 2012. Mining Permit Applications Database. Pretoria.

DlAmbulo, N. and MotSIE, R. 2014. Industrial minerals overview. South Africa's Minerals Industry. Department of Mineral Resources, Pretoria.

DRESCHLER, B. 2001. Small scale mining and sustainable development within SADC region. Minerals Mining and Sustainable Development (MMDS) Report. no. 84. August 2001.

ENGINEERING NEws. 1999. http://www.engineeringnews.co.za/printversion/madunax2019s-pledge-to-south-africax2019s-3-000-illegalmines-1999-02-26 [Accessed 8 August 2016].

Focus GROUP DISCUSSION WITH SALT MINERS. Soutpan. Free State. 29 October 2014.

Government GazetTe. 2002, Mineral Petroleum Resource and Development Act (No. 28 of 2002) (MPRDA). Republic of South Africa. 10 October 2002.

Government GazetTe. 2013, Mineral and Petroleum Resources Development Amendment Bill. Republic of South Africa. 31 May 2013.

Government Gazette. 1994. White Paper on Reconstruction and Development Programme (RDP). Cape Town, 15 November 1994.

Government GazetTe. 2009. Mineral and Petroleum Resource Development Amendment Act, 2008. Cape Town, 21 April 2009.
HoadLey, M. and LimpitLaw, D. 2004. The artisanal and small scale mining sector and sustainable livelihoods. Small Scale Mining Conference, Mintek, Randburg, South Africa, 9 September 2004. pp. 1-9.

InTERNATIONAL LABOUR ORGANIZATION (ILO). 1999. Social and labour issues in small-scale mines. Geneva, Switzerland.

Kogel, J.E., TrivedI, N.C., BARKER, J.M., and KRUKOWSKI, S.T. 2006. Industrial Minerals and Rocks: Commodities, Markets and Uses. Society for Mining, Metallurgy and Exploration, Littleton, CO.

Ledwaba, P., Malatsi, R., Moeletsi, R., and Mosena, C. 2013. Understanding the small-scale mining industry in the Northern Cape - Primary focus on tiger's eye. Internal Report. Mintek, Randburg, South Africa.

LEDWABA, P. and NHLENGETHWA, K. 2016. When policy is not enough: prospects and challenges of artisanal and small-scale mining in South Africa. Journal of Sustainable Development Law and Policy, vol. 7, no. 1. http://www.ajol.info/index.php/jsdlp/article/view/140511

LEGOALE, T. 2014. Monitoring and evaluation of previously trained SMMEs. Internal Report. Mintek, Randburg, South Africa.

LovE, J. 2015. Report of the SAHRC investigative hearing. Issues and challenges in relation to unregulated artisanal underground and surface mining activities in South Africa. A report prepared for the South African Human Rights Commission (SAHRC).

MaLATSI, R., LEDWABA, P., and MAvuso, M. 2012. Industrial minerals database. Internal Report. Mintek, Randburg, South Africa.

MARRIOTT, A. 2008. Extending health and safety protection to informal workers: an analysis of small scale mining in KwaZulu-Natal. Research report no. 76. School of Development Studies, University of KwaZulu-Natal. January 2008.

Mine Health and SAfEty Council. 2011. The Mine Health and Safety Council work on the small scale mining project. Johannesburg.

Mining QuAlifications AuthoRITy (MOA). 2014. Sector skills plan for the mining and minerals sector submitted by the Mining Qualifications Authority (MQA) to the Department of Higher Education and Training Update 20152020. p. 27.

Mining WeEkLy OnLine. 2009. SA courts now recognise illegal mining as organised crime, http://www.miningweekly.com/print-version/sa-courtsnow-recognise-illegal-mining-as-organised-crime-2009-11-13 [Accessed 8 October 2014].

Mutemeri, N. and Petersen, F.W. 2002. Small-scale mining in South Africa: Past, present and future. Natural Resource Forum.

Mutemeri, N., Sellick, N., and MTEGHA, H. 2010. What is the status of smallscale mining in South Africa?. Discussion document for the MQA SSM Colloquium, August 2010.

National Treasury. 2015. Public-sector infrastructure update. http://www.treasury.gov.za/documents/national\%20budget/2015/review/ Annexure\%20b.pdf [Accessed 8 August 2016].

NHLENGETwA, K. and Hein, K. 2015. Zama-Zama mining in the Durban Deep/Roodepoort area of Johannesburg, South Africa: An invasive or alternative livelihood? The Extractive Industries and Society.

NHLENGETWA, K. 2016. Why it doesn't make sense that all informal mining is deemed illegal. http://theconversation.com/why-it-doesnt-make-sensethat-all-informal-mining-is-deemed-illegal-57237 [Accessed 13 April 2016].

SCOTT, R., RockEY, N., and Hudson, R. 1998. The status of small-scale mining in South Africa - A preliminary study. Minerals and Energy Policy Centre and The Marketing Shop. October 1998.

Solomons, I. 2015. Artisanal, small-scale mining could stimulate huge socioeconomic benefits. http://www.miningweekly.com/print-version/artisanaland-small-scale-mining-sector-needs-more-support---dmr-2015-07-17 [Accessed 8 August 2016].

SoLomons, M. 2012. The rise of resource nationalism: A resurgence of state control in an era of free markets or the legitimate search for a new equilibrium? A study to inform multi-stakeholder dialogue on state-participation in mining. Southern African Institute of Mining and Metallurgy, Johannesburg.

http://www.saimm.co.za/Conferences/ResourceNationalism/ResourceNatio nalism-20120601.pdf

StATISTICS SA. 2016. Quarterly Labour Force Survey. 9 May 2016. Pretoria.

World Bank. 2013. Artisanal and small scale mining. http://www.worldbank.org/en/topic/extractiveindustries/brief/artisanaland-small-scale-mining [accessed 8 August 2016]. 